\title{
Haemato-biochemical changes in tuberculosis infected and healthy Asian elephants (Elephas maximus) from South India"

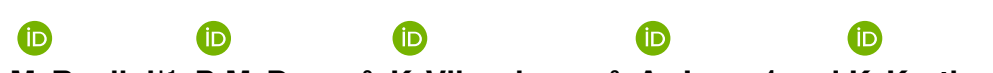

M. Ranjini ${ }^{\star 1}$, P. M. Deepa ${ }^{2}$, K. Vijayakumar ${ }^{3}$, A. Janus ${ }^{4}$ and K. Karthyayini ${ }^{5}$ Department of Veterinary Epidemiology and Preventive Medicine, College of Veterinary and Animal Sciences, Pookode- 673576 Kerala Veterinary and Animal Sciences University, Kerala, India.

Citation: Ranjini, M., Deepa, P. M., Vijayakumar, K., Janus, A. and Karthyayini, K. 2021. Haematobiochemical changes in tuberculosis infected and healthy Asian elephants (Elephas maximus) from South India. J. Vet. Anim. Sci. 52(4): 345-349

DOI: https://doi.org/10.51966/jvas.2021.52.4.345-349

Received: 10.02 .2021

Accepted: 26.03.2021

Published: 15.12.2021

Tuberculosis is known to be a disease of elephants for the past 2000 years. The main causative agent isolated from reported tuberculosis (TB) cases were Mycobacterium tuberculosis. The study focuses on the haematological and serum biochemical changes in the blood of TB infected Asian elephants (Elephas maximus). Twelve apparently healthy elephants and twelve TB infected elephants (confirmed by trunk wash smear positive for acid fast bacilli) were selected for the study. Neonates, pregnant elephants and elephants in musth were not included in the study. The study animals were subjected to haematological and serum biochemical evaluation. The data were analysed statistically. The results showed a significant increase in total leukocyte count, lymphocyte count, monocyte count, thrombocyte count and ESR in TB affected animals compared with apparently healthy animals. Serum creatinine, total bilirubin, direct bilirubin, globulin was significantly high in TB affected animals compared with healthy controls. Assessment of haematological and serum biochemical parameters in TB affected elephants aid in diagnosis and tracking of the infection.

Key words: Elephant, tuberculosis, haematology, serum biochemistry

Running title: Haemato-biochemical changes in tuberculosis infected and healthy Asian elephants

"Forms part of MVSc thesis submitted to Kerala Veterinary and Animal Sciences University, Pookode, Wayanad, Kerala

1. *M.V.Sc Scholar and corresponding author, Email: manuelranjini@gmail.com Phone: 08078421265

2. Assistant Professor and Head (i/c)

3. Professor and Head, Department of Veterinary Epidemiology and Preventive Medicine, College of Veterinary and Animal Science, Mannuthy

4. Assistant Professor

5. Professor, Department of Veterinary Physiology, College of Veterinary and Animal Science, Mannuthy

Copyright: (C) 2021 Ranjini et al. This is an open access article distributed under the terms of the Creative Commons Attribution 4.0 International License (http://creativecommons.org/licenses/by/4.0/), which permits unrestricted use, distribution, and reproduction in any medium, provided the original author and source are credited. 
Tuberculosis is one of the major infectious diseases known to the elephant world for the past twenty centuries (Mikota et al., 2001). As the years go by, the number of TB cases are hiking and the elephant population is declining (Lewerin et al., 2005). There can be a plethora of reasons for the decline in the population, however TB can be one of the many reasons. Mycobacterium tuberculosis being a devious organism, has complex mechanisms to survive and multiply in the body without being detected by immune system. The course of the disease and its immunobiology are poorly studied in elephants. Although the complex pathogenesis of disease is still under study, the associated immune mediated systemic inflammation has been reported to be significant (Rohini et al., 2016; Ottenhoff et al., 2012) which results in alterations in the blood and serum parameters. If the TB infected animal has an underlying condition or infection which can cause immunosuppression, abnormalities in blood could be much blatant. There are very limited studies regarding the haematological and serum biochemical changes during the course of TB infection in elephants. This study aims to furnish insights into the serum biochemical and haematological changes during TB infection and evaluation of the variability of blood parameters of TB infected elephants when compared to that of apparently healthy animals.

\section{Materials and methods}

Twelve apparently healthy adult captive Asian elephants (Elephas maximus) which were negative for acid fast bacilli in trunk wash smear were selected for the study and were included in the healthy group. Twelve animals with trunk wash smear positive for acid fast bacilli (AFB) were selected and included in the TB infected group. Neonates, elephants in gestation, in lactation and in musth were not included in the study. The selected animals were subjected to haematological and serum biochemical evaluation.

\section{Blood collection}

Animals were placed in lateral recumbency. Blood was drawn from superficial marginal vein located at the external aspect of the ear using, sterile 16-gauge disposable needle into a vacutainer tube.

\section{Haematology evaluation}

Blood samples were collected in $2 \mathrm{~mL}$ EDTA vacutainer tubes for the evaluation of haematological parameters (Orphee mythic 18vet - analyzer) viz. haematocrit (HCT), haemoglobin $(\mathrm{Hb})$, total erythrocyte count (TEC), mean corpuscular volume (MCV), mean corpuscular haemoglobin $(\mathrm{MCH})$, mean corpuscular haemoglobin concentration $(\mathrm{MCHC})$, red cell distribution width (RDW), total leukocyte count (TLC), erythrocyte sedimentation rate (ESR), platelet count and mean platelet count on the day of presentation.

\section{Serum biochemical evaluation}

Blood samples were collected in $4 \mathrm{~mL}$ serum vacutainer tube for the evaluation of serum biochemical parameters (Master T, Hospitex diagnostics, Italy) viz. blood urea nitrogen (BUN), creatinine, total bilirubin, direct bilirubin, indirect bilirubin, glucose, total protein, albumin, globulin, albumin globulin ratio, cholesterol, aspartate aminotransferase (AST), alanine aminotransferase (ALT), alkaline phosphatase (ALP) on the day of presentation.

\section{Statistical analysis}

These data were evaluated and analysed by SPSS version 25. In order to compare quantitative variables in TB infected and heathy groups, independent t-test were performed for normally distributed variables. Significance difference were assessed at both 0.01 and 0.05 levels.

\section{Result and discussion}

All the animals included in the healthy group were apparently normal and did not show any signs of systemic disorder or infection. Elephants belonging to TB infected group had mild mucus discharges from the trunk. Nonetheless, all the animals were active and alert, with normal behaviour and feed intake.

Blood samples were collected for haematological and serum biochemical 
analysis on the day of presentation and were evaluated. The values obtained were statistically analysed. The mean and standard error of mean for the various parameters were tabulated (Table 1, 2). In the present study, total erythrocyte count (TEC), haemoglobin $(\mathrm{Hb})$ and haematocrit $(\mathrm{HCT})$ values had no significant difference between TB infected and healthy group. This is in contrast with the studies done in haematology of TB infected humans (Abdelkareem et al. 2015, Rohini et al., 2016, Abay et al., 2018). Nevertheless, individual values for TEC, HCT and $\mathrm{Hb}$ showed minor decrease among TB infected group with that of healthy control group. This variability may be due to the dissimilar hydration status of elephants or different stages of infection in the selected animals. The TLC, lymphocytes, MCV, $\mathrm{MCH}$ and platelet count were significantly high in TB infected group. This in accordance with Abdelkareem et al. (2015) who found that 49 per cent of patients with pulmonary TB (PTB) had leukocytosis. Yaranal et al. (2013) and Rohini et al. (2016) found that all of patients with PTB had leucocytosis. There was a significant thrombocytosis in TB infected group which is in accordance with the study by Rathod et al. (2017) who speculated the potential use of thrombocyte count as a marker for TB and found that 75 per cent of the TB infected patients had thrombocytosis. The ESR values obtained from the study had significant difference with that of healthy controls which is in agreement with the previously published studies (Oliva et al., 2008; Rohini et al., 2016; Kahase et al., 2020). Mandal and Chaven (2016) suggested that the increment in the ESR values were a common observation in active TB cases. The reasons for the increment in ESR values might be due to the increase in fibrinogen, immunoglobulins and C-reactive protein in the blood, which is a common finding in conditions like TB, inflammation and malignant conditions (Cheesbrough, 2005).

Table 1. Comparison of haematological parameters between TB infected and healthy group

\begin{tabular}{|c|c|c|c|c|c|c|}
\hline \multirow{2}{*}{$\begin{array}{l}\text { SI. } \\
\text { No. }\end{array}$} & \multirow[b]{2}{*}{ Parameters } & \multirow[b]{2}{*}{ Unit } & \multicolumn{2}{|c|}{ Observation } & \multirow[b]{2}{*}{ t- value } & \multirow[b]{2}{*}{ P-value } \\
\hline & & & $\begin{array}{l}\text { TB infected } \\
\text { group }\end{array}$ & Healthy group & & \\
\hline 1 & Total Leukocyte Count & $10^{3} / \mu \mathrm{L}$ & $24.67 \pm 0.61$ & $21.57 \pm 0.21$ & $4.849^{\star \star}$ & $<0.001$ \\
\hline 2 & Lymphocytes & $10^{3} / \mu \mathrm{L}$ & $16.29 \pm 0.53$ & $11.68 \pm 0.16$ & $8.377^{\star \star}$ & $<0.001$ \\
\hline 3 & Monocytes & $10^{3} / \mu \mathrm{L}$ & $2.48 \pm 0.14$ & $3.71 \pm 0.11$ & $6.846^{\star \star}$ & $<0.001$ \\
\hline 4 & Granulocytes & $10^{3} / \mu \mathrm{L}$ & $5.88 \pm 0.50$ & $6.05 \pm 0.04$ & $0.346^{\mathrm{ns}}$ & 0.736 \\
\hline 5 & Lymphocytes & $\%$ & $66.31 \pm 1.91$ & $54.23 \pm 0.50$ & $6.119^{\star \star}$ & $<0.001$ \\
\hline 6 & Monocytes & $\%$ & $10.07 \pm 0.58$ & $17.51 \pm 0.40$ & $10.510^{\star \star}$ & $<0.001$ \\
\hline 7 & Granulocytes & $\%$ & $23.63 \pm 1.61$ & $28.26 \pm 0.30$ & $2.820^{\star}$ & 0.016 \\
\hline 8 & Total Erythrocyte Count & $10^{6} / \mu \mathrm{L}$ & $3.85 \pm 0.10$ & $3.76 \pm 0.02$ & $0.864^{\mathrm{ns}}$ & 0.404 \\
\hline 9 & Haemoglobin & $\mathrm{g} / \mathrm{dL}$ & $14.11 \pm 0.39$ & $13.53 \pm 0.02$ & $1.462^{\mathrm{ns}}$ & 0.172 \\
\hline 10 & Haematocrit & $\%$ & $50.15 \pm 1.39$ & $47.95 \pm 0.27$ & $1.556^{\mathrm{ns}}$ & 0.146 \\
\hline 11 & Mean Corpuscular Volume & $\mathrm{fL}$ & $130.33 \pm 0.46$ & $127.33 \pm 0.09$ & $6.384^{\star \star}$ & $<0.001$ \\
\hline 12 & $\begin{array}{l}\text { Mean Corpuscular } \\
\text { Haemoglobin }\end{array}$ & $\mathrm{pg}$ & $36.64 \pm 0.31$ & $34.13 \pm 1.05$ & $2.291^{\star}$ & 0.039 \\
\hline 13 & $\begin{array}{l}\text { Mean Corpuscular } \\
\text { Haemoglobin Concentration }\end{array}$ & $\mathrm{g} / \mathrm{dL}$ & $28.10 \pm 0.21$ & $28.16 \pm 0.15$ & $0.229^{n s}$ & 0.821 \\
\hline 14 & Red Cell Distribution Width & $\%$ & $13.82 \pm 0.18$ & $14.24 \pm 0.05$ & $2.209^{\star}$ & 0.046 \\
\hline 15 & Platelet Count & $10^{3} / \mu \mathrm{L}$ & $1295 \pm 149.02$ & $850.58 \pm 26.99$ & $2.935^{\star}$ & 0.013 \\
\hline 16 & Mean Platelet Volume & $f L$ & $4.62 \pm 0.09$ & $5.40 \pm 0.06$ & $6.950^{\star *}$ & $<0.001$ \\
\hline 17 & $\begin{array}{l}\text { Erythrocyte Sedimentation } \\
\text { Rate }\end{array}$ & $\mathrm{mm} / \mathrm{hr}$ & $4.91 \pm 0.09$ & $3.88 \pm 0.15$ & $5.770^{\star \star}$ & $<0.001$ \\
\hline
\end{tabular}

** Significant at 0.01 level; * Significant at 0.05 level; ns Non-significant 
Table 2. Comparison of Serum Biochemical Parameters between TB infected and healthy group

\begin{tabular}{|c|l|c|c|c|c|c|}
\hline \multirow{2}{*}{$\begin{array}{c}\text { SI. } \\
\text { No. }\end{array}$} & \multicolumn{1}{|c|}{ Parameters } & \multirow{2}{*}{ Unit } & \multicolumn{2}{|c|}{ Observation } & & \\
\cline { 5 - 7 } & & & $\begin{array}{c}\text { TB infected } \\
\text { group }\end{array}$ & Healthy group & t-value & P-value \\
\hline $\mathbf{1}$ & Blood Urea Nitrogen & $\mathrm{mg} / \mathrm{dL}$ & $12.07 \pm 0.16$ & $11.82 \pm 0.22$ & $0.922^{\text {ns }}$ & 0.367 \\
\hline $\mathbf{2}$ & Greatinine & $\mathrm{mg} / \mathrm{dL}$ & $1.96 \pm 0.07$ & $1.35 \pm 0.05$ & $6.708^{\star \star}$ & $<0.001$ \\
\hline $\mathbf{3}$ & Total Bilirubin & $\mathrm{mg} / \mathrm{dL}$ & $0.98 \pm 0.13$ & $0.66 \pm 0.07$ & $2.221^{\star}$ & 0.037 \\
\hline $\mathbf{4}$ & Direct Bilirubin & $\mathrm{mg} / \mathrm{dL}$ & $0.39 \pm 0.04$ & $0.29 \pm 0.03$ & $2.123^{\star}$ & 0.045 \\
\hline $\mathbf{5}$ & Indirect Bilirubin & $\mathrm{mg} / \mathrm{dL}$ & $0.59 \pm 0.12$ & $0.37 \pm 0.05$ & $1.658^{\text {ns }}$ & 0.112 \\
\hline $\mathbf{6}$ & Glucose & $\mathrm{mg} / \mathrm{dL}$ & $110.12 \pm 6.26$ & $113.47 \pm 5.35$ & $0.407^{\text {ns }}$ & 0.688 \\
\hline $\mathbf{7}$ & Total Protein & $\mathrm{g} / \mathrm{dL}$ & $9.75 \pm 0.13$ & $10.03 \pm 0.14$ & $1.441^{\text {ns }}$ & 0.164 \\
\hline $\mathbf{8}$ & Albumin & $\mathrm{g} / \mathrm{dL}$ & $2.85 \pm 0.06$ & $3.11 \pm 0.09$ & $2.478^{\star}$ & 0.021 \\
\hline $\mathbf{9}$ & Globulin & $\mathrm{g} / \mathrm{dL}$ & $7.18 \pm 0.14$ & $6.61 \pm 0.13$ & $2.983^{\star *}$ & 0.007 \\
\hline $\mathbf{1 0}$ & A/G Ratio & - & $0.40 \pm 0.01$ & $0.49 \pm 0.02$ & $3.334^{\star \star}$ & 0.003 \\
\hline $\mathbf{1 1}$ & Cholesterol & $\mathrm{mg} / \mathrm{dL}$ & $31.41 \pm 1.98$ & $32.13 \pm 1.79$ & $0.272^{\text {ns }}$ & 0.788 \\
\hline $\mathbf{1 2}$ & Aspartate Aminotransferase & $\mathrm{IU} / \mathrm{L}$ & $20.93 \pm 2.10$ & $22.89 \pm 1.02$ & $0.838^{\text {ns }}$ & 0.411 \\
\hline $\mathbf{1 3}$ & Alanine Aminotransferase & $\mathrm{IU} / \mathrm{L}$ & $17.55 \pm 2.06$ & $15.34 \pm 1.45$ & $0.879^{\text {ns }}$ & 0.389 \\
\hline $\mathbf{1 4}$ & Alkaline Phosphatase & $\mathrm{IU} / \mathrm{L}$ & $290.75 \pm 23.67$ & $259 \pm 30.23$ & $0.827^{\text {ns }}$ & 0.417 \\
\hline
\end{tabular}

** Significant at 0.01 level; * Significant at 0.05 level; $n$ s Non-significant

The serum biochemistry results obtained in the study projects significant difference in albumin, globulin and albumin globulin ratio. In the diseased group, albumin value attained was lower and globulin value was higher on comparison with the healthy group. Further the albumin globulin ratio attained was lower in TB infected group. This is in agreement with the previous reports (Wong and Saha, 1989; Shingdang et al., 2016). The BUN, cholesterol, indirect bilirubin, AST, ALT and ALP values have no significant difference between the groups (Giri et al., 2007). However mean cholesterol level in TB infected group is comparatively less which agrees with Miner et al., (2009) who suggested that cholesterol is crucial for the persistence of the organism. In the present study, the mean ALP value is nonsignificantly increased in TB infected group. Creatinine value showed significant increase in TB infected group, which is in accordance with Giri et al. (2007). Total bilirubin and direct bilirubin values were found to be significantly increased TB group this may be attributable to some underlying hepatic conditions or any intravascular haemolysis (Kerr, 2002).

\section{Conclusion}

Inthe presentstudy, thehaematological and serum biochemical parameters differed among TB infected and heathy group. In the context of tuberculosis infection, the changes in the blood chemistry and the failure of these values to return to the normal for a prolonged period can indicate persistent infection. Further blood profiling can aid in correlating the severity of the disease (Kahase et al., 2020). The results of the study demonstrated significant increase in haematological parameters viz TLC, lymphocytes, monocytes, MCV, MCH, RDW and platelets. In serum biochemistry there was significant increase in creatinine, total bilirubin, direct bilirubin and globulin. These indices have the potential to form a part of preliminary diagnosis and tracking the response to treatment. Large scale studies are required to substantiate and accurately determine the association of blood chemistry and TB infection in elephants.

\section{Acknowledgement}

The authors are thankful to the Kerala Veterinary and Animal Sciences University for providing the facilities needed for carrying out the research.

\section{Conflicts of interest}

The authors declare that they have no conflict of interest. 


\section{References}

Abay, F., Yalew, A., Shibabaw, A. and Enawgaw, B. 2018. Hematological abnormalities of pulmonary tuberculosis patients with and without HIV at the University of Gondar Hospital, Northwest Ethiopia: a comparative cross-sectional study. Tuberc. Res. Treat. 5740951. https://doi.org/10.1155/2018/5740951

Abdelkareem, Y., Hashim, A.M. and Abdelazeem, H. 2015. Hematological changes in pulmonary tuberculosis. AlAzhar Assiut Med. J. 13: 224-229.

Cheesbrough, M. 2005. District laboratory practice in tropical countries. ( $2^{\text {nd }}$ ed.) Cambridge university press. $331 \mathrm{p}$.

Giri, K., Kaufman, G.E. andDhakal, I.P.2011.The relationship between blood parameter and mycobacterium culture status in captive elephants of Nepal. Nepalese Vet. J. 30: 119-129.

Kahase, D., Solomon, A. and Alemayehu, M. 2020. Evaluation of Peripheral Blood Parameters of Pulmonary Tuberculosis Patients at St. Paul's Hospital Millennium Medical College, Addis Ababa, Ethiopia: Comparative Study. J. Blood Med. 11:115-121.

Kerr, M. G. 2002. Laboratory Medicine Clinical Biochemistry and Haematology. Blackwell Scientific publications Ltd., Great Britain. 2nd ed. 127-135p.

Lewerin, S.S., Eld, K., Bölske, G., Olsson, S.L., Röken, B., Ghebremichael, S., Koivula, T. and Källenius, G. 2005. Outbreak of Mycobacterium tuberculosis infection among captive Asian elephants in a Swedish zoo. Vet. Rec. 156: 171-175.

Mandal, S.K. and Chavan, L. 2016. Erythrocyte sedimentation rate values in cases of active tuberculosis without HIV coinfection. J. Med. Sci. clin. Res. 4:1315613159
Mikota, S.K., Peddie, L., Peddie, J., Isaza, R., Dunker, F., West, G., Lindsay, W. and Larsen, R.S. 2001. Epidemiology and diagnosis of Mycobacterium tuberculosis in captive Asian elephants (Elephas maximus). J. Zoo Wildl. Med. 32: 1-16.

Miner, M.D., Chang, J.C., Pandey, A.K., Sassetti, C.M. and Sherman, D.R. 2009. Role of cholesterol in Mycobacterium tuberculosis infection. Indian J. Exp. Biol. 47: 407-411.

Oliva, V.M., Cezário, G.A.G., Cocato, R.A and Marcondes-Machado, J. 2008. Pulmonary tuberculosis: hematology, serum biochemistry and the relation with the disease duration. J. Venom. Anim. Toxins incl. Trop. Dis. 14: 71-81.

Ottenhoff, T.H. 2012. New pathways of protective and pathological host defense to mycobacteria. Trends Microbiol. 20: 419-428.

Rathod, S., Samel, D.R., Kshirsagar, P. and Pokar, M. 2017. Thrombocytosis: can it be used as a marker for tuberculosis. Int. J. Res. Med. Sci. 5: 3082-3086.

Rohini, K., Bhat, M.S., Srikumar, P.S. and Kumar, A.M. 2016. Assessment of hematological parameters in pulmonary tuberculosis patients. Indian J. Clin. Biochem. 31:332-335.

Shingdang, J., Bot, Y., Ojo, O., Edeh,O., Essien,C., Bwende, E., Okolie, C. and Ekwempu, A.I. 2016. Serum Albumin/ Globulin ratio in Tuberculosis and HIV Patients any Relationship?. Mycobact. Dis. 6:199.

Wong, C.T. and Saha, N. 1989. Serum immunoglobulin and acute phase protein concentrations in pulmonary tuberculosis patients in Singapore. Trop. Geogr. Med. 41: 218-221.

Yaranal, P.J., Umashankar, T. and Harish, S.G. 2013. Hematological profile in pulmonary tuberculosis. Int. J. Health Rehabil. Sci. 2: 50-55. 